\title{
The Capability of Black Soldier Fly, Hermetia Illuncens, to Consume Some Weeds in Vegetable Field
}

\author{
Y Sanjaya $^{1}$, Suhara $^{2}$, M. Nurjhani ${ }^{3}$, M Halimah $^{4}$ \\ $\left\{\right.$ yayan@upi.edu $\left.{ }^{1}\right\}$ \\ Biologi Department, Universitas Pendidikan Indonesia, Jl.Dr. Setiabudi N0.229, Bandung, \\ Indonesia $^{1,2,3}$, Biology Study program, Univeritas Pasundan J1. Taman Sari No. 6-8, Bandung, Indonesia ${ }^{4}$
}

\begin{abstract}
Weed in the agriculture field is needed to reduce. So It is need something environmentally tool to conserve agriculture. One promising uses Black Soldier Fly (BSF) larvae. The larvae capability to consume some weeds were presented. Descriptive research was conducted by investigating the role of BSF on some weeds i.e ki rinyuh (Chromolaena odorata), Babadotan (Ageratum conyzoides), rumput gajah (Pennisetum purpreum). Each was given BSF larvae with $150 \mathrm{~g}$, $200 \mathrm{gr}$ and $250 \mathrm{gr}$ of weight on $500 \mathrm{gr}$ weed, The result showed that BSF larvae at $150 \mathrm{~g}$ of weight convert weed between 80 $100 \%$, on $200 \mathrm{mg}$ convert $75 \%-97 \%$, on $250 \mathrm{mg}$ can convert $80 \%-100 \%$ in four day. The mortality of BSF larvae on Chromolaena odorata was $10 \%$, Ageratum conyzoides was $6 \%$, Pennisetum purpreum was $0 \%$. This showed BSF larvae can be converted weed into BSFlarvae biomass.
\end{abstract}

Keywords: Hermetia illucens, weeds, weight, bioconversion

\section{Introduction}

The waste product is a big problem in Indonesia. Various wastes have not been systematically resolved including the remnants of weeds. Weed is a plant that grows and competes with competing plants in terms of obtaining nutrients. To overcome this, farmers usually deal with it by weeding and stacking it, sometimes even burning. In large numbers, weeds will be a problem for the environment and sources of pests and diseases [1].

One solution is to use Black Soldier Fly larvae that they can transform garbage into something useful. According to Shepard et al. [2] The bio composting process of BSF larvae is quite effective so that it can be used on a large scale where the accumulation of organic waste material especially animal feed can be polluted. According to Diener [3] in this case, BSF larvae can consume organic material widely, the fund is very potential in the management of waste materials. The purpose of this study was to determine the effect of kitchen waste, harvest waste, and weed waste as BSF feed on the durability and conversion of waste into biomass. To help convert the remaining weeds, we will examine the effect of Black Soldier Fly on three types of weeds as feed. 


\section{Research methods}

The research method used is a descriptive research method, describing the process of changing organic weeds into biomass. Research procedures, prepared ki rinyuh (Chromolaena odorata), Babadotan (Ageratum conyzoides), elephant grass (Pennisetum purpreum) for $500 \mathrm{gr}$. Bsf of $50 \mathrm{gr}, 100 \mathrm{gr}$, and $150 \mathrm{gr}$ are weighed, and the number of larvae is calculated for each treatment and observed for up to four days

\section{Results and Discussion}

The results showed that the Black Solder Fly in the three weeds i.e ki rinyuh (Chromolaena odorata), Babadotan (Ageratum conyzoides), elephant grass (Pennisetum purpreum) (Figure 1) were able to convert waste by an average of $80 \%$.

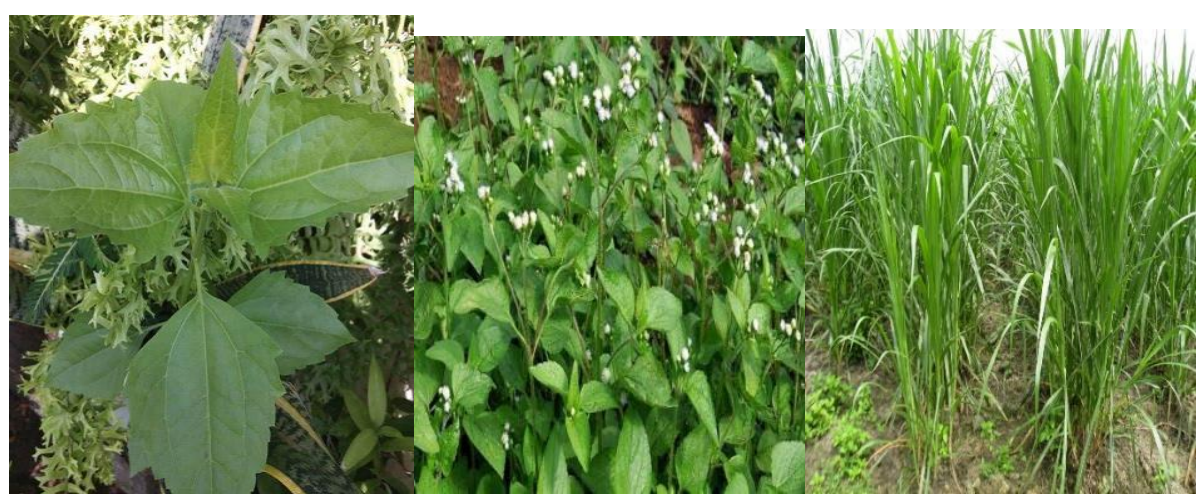

Fig. 1. Picture of C. odorata, A. conyzoides, and P. purpreum).

Based on Table 1, from the observations of BSF with an initial weight of $150 \mathrm{gr}$. It is able to convert weeds into biomass almost doubled. The number of live births each was $96.67 \%$; $97 \% ; 100 \%$

The same pattern occurs in Table 2, from the observations of BSF with an initial weight of $100 \mathrm{gr}$ able to convert house waste, vegetable waste, and weed waste into $200 \mathrm{gr}, 250 \mathrm{gr}$, and 200 gr respectively. It can be seen that vegetable waste as food for BSF produces the highest body weight while house waste and weed rubbish are able to change biomass weighing 200 grams for each. Based on observations of larvae with higher weight able to convert higher biomass

Table 1. Role of weeds as BSF Larvae feed with an initial weight of $150 \mathrm{gr}$.

\begin{tabular}{lcccc}
\hline Weeds & $\begin{array}{l}\text { Initial weight } \\
\text { (total) }\end{array}$ & Total initial/gram & End weight (total) & End Initial/gram \\
\hline C. odorata & 600 & 150 & 580 & 262,5 \\
A. conyzoides & 610 & 150 & 590 & 270
\end{tabular}




\begin{tabular}{lcccc}
\hline Weeds & $\begin{array}{l}\text { Initial weight } \\
\text { (total) }\end{array}$ & Total initial/gram & End weight (total) & End Initial/gram \\
\hline P. purpreum & 605 & 150 & 605 & 292,5 \\
\hline
\end{tabular}

Table 2. The role of weeds as BSF larvae feed with an initial weight of $200 \mathrm{gr}$.

\begin{tabular}{lllll}
\hline Weeds & $\begin{array}{l}\text { Initial weight } \\
\text { (total) }\end{array}$ & Total initial/gram & End weight (total) & End Initial/gram \\
\hline C. odorata & 805 & 200 & 770 & 200 \\
A. conyzoides & 800 & 200 & 780 & 250 \\
P. purpreum & 810 & 200 & 810 & 200 \\
\hline
\end{tabular}

In Table 3, it can be seen that all BSF treatments for organic waste are the treatments that produce the highest weight and also survival rate of them are $87 \%, 91 \%, 100 \%$ Insects have a high feed efficiency and low feed conversion ratio, with the ability to be maintained in a biowaste stream; they are able to grow and multiply in waste materials [3]. Insects can eat waste material and converted it into highly desirable feed for livestock. Insects that have been intensively studied and found to be the most promising for industrial feed production are black army flies (Hermetia illucens), common household fly larvae (Musca domestica), silkworms (Bombyx mori) and yellow worms (Tenebrio molitor) [4].

The buildup of organic waste, especially from restaurants, fish processors and farmers, can cause pollution. The accumulation of organic waste, especially in livestock facilities, can be a potential pollution issue. The black army fly, Hermetia illucens L. (Diptera: Stratiomyidae), can consume a variety of organic materials and has the potential to be used in waste management [5].

In addition, the prepupa stage of this insect can be harvested and used as a valuable nutritious feed for livestock animals [5]. Five types of waste with various organic source materials were specifically chosen to evaluate the consumption ability and reduction of black army fly larvae [6] . H. illucens able to reduce all types of waste Organic waste that may cause problems or recycling opportunities generally divided into four categories: 1) Food processing and factory waste, 2) Food used by consumers (restaurants and households), 3) Dirt from feeding operations limited livestock, and 4) Animal remains and innards [7]. Based on observations it appears that Black Soldier Fly can reduce organic waste by leaving no side effects

Table 3. The role of weeds as BSF larvae feed with an initial weight of $250 \mathrm{gr}$.

\begin{tabular}{lllll}
\hline Weeds & $\begin{array}{l}\text { Initial weight } \\
\text { (total) }\end{array}$ & Total initial/gram & End weight (total) & $\begin{array}{l}\text { End } \\
\text { Initial/gram }\end{array}$ \\
\hline C. odorata & 1210 & 250 & 1054 & 450 \\
A. conyzoides & 1205 & 250 & 1100 & 475 \\
P. purpreum & 1207 & 250 & 1207 & 500 \\
\hline
\end{tabular}




\section{References}

[1] Rao, A. N., Johnson, D. E., Sivaprasad, B., Ladha, J. K., and Mortimer, A. M.: Weed management in direct-seeded rice. Adv. Agron. 93. pp. 153-255 (2007)

[2] Sheppard, C., Newton, G. L., Thompson, S. A., and Savage, S.: A value added manure management system using the black soldier fly. Bioresource Technology. 50. pp. 275-279 (1994)

[3] Diener, S. and Zurbrugg, C.: Black Soldier Fly Larvae for Organic Waste Treatment - Prospects and Constraints. In: 2nd International Conference on Solid Waste Management in the Developing Countries (2011)

[4] Food and Agriculture Organization: Livestock Impacts on the Environment (2006)

[5] Barry, T., 2004. Evaluation of the Economic, Social, and Biological Feasibility of Bioconverting Food Wastes with the Black Soldier Fly (Hermetia illucens). PhD. University of North Texas.

[6] Li, Q. et al.: Bioconversion of dairy manure by black soldier fly (Diptera: Stratiomyidae) for biodiesel and sugar production. Waste Management. 31. pp.1316-1320 (2011)

[7] Liu, Q. et al.: Short-term effect of biochar and compost on soil fertility and water status of a Cambisol in NE Germany under field conditions. Journal of Plant Nutrition and Soil Science, [Online]. 2012 (000), pp.1-10 (2012) 